\title{
Tragedy of Commons: Analysis of Oil Spillage, Gas Flaring and Sustainable Development of the Niger Delta of Nigeria
}

\author{
AKPOMUVIE, ORHIOGHENE, BENEDICT Ph.D \\ DELTA STATE UNIVERSITY, SOCIOLOGY DEPARTMENT \\ P.M.B, ABRAKA, DELTA STATE, NIGERIA \\ E-mail: bakpomuvie@gmail.com
}

Received: November 13, 2010

Accepted: January 24, 2011

doi:10.5539/jsd.v4n2p200

\begin{abstract}
The hue and cry about the stark despoliation of the Niger Delta has been ongoing; and the issues at stake have centered mostly on the gross and glaring underdevelopment in the area despite the vast resources that have accrued to the Nigerian state from the region. Perhaps the most disturbing, is that oil exploration and exploitation in the Niger Delta is carried out without regard to international health and safety standards or observed minimum levels of protection to the environment from pollution arising from oil spillage and gas flaring. This paper is therefore geared towards addressing the problem of oil spillage, gas flaring and sustainable development in the region. In addition, it promotes the interest in getting to grips with a clear appreciation of the importance and implications of embracing sustainable development through Environmental Impact Assessment (EIA). This is because EIA has become an avenue whereby the principles of sustainability can be integrated into a country's development activities. Finally, the paper contends that ways of controlling environmental hazards have been clearly stated in the various laws and decrees promulgated in Nigeria. Those efforts therefore, should be focused on implementing these laws and decrees as a means of achieving sustainable development for the region.
\end{abstract}

Keywords: Boom, Environmental impact assessment, Degradation, Poverty, Sustainability, Pollution, Exploration, Exploitation

\section{Introduction}

The fan shaped Niger Delta which is the third largest in the world after the Mississippi and Pantanal (S/W Brazi) lies between latitude $4^{\circ}$ and $6^{\circ}$ North of the equator and longitudes $5^{\circ}$ and $9^{\circ}$ east of the Greenwich Meridian. The South-North extent of $4-6^{\circ}$ North of the equator is expressly defined by the Great Atlantic Ocean in the South to Aboh (Delta State) in the North where River Niger forks into River Nun and River Forcados at a village called Obotor. Aboh is a few kilometers north of this village but it is a relatively bigger settlement than Obotor. The East-West extension is from the boundary of the Bonny River to Sapele River, Delta State (Tamuno, 2008).

This implies that the East-West extent of approximately $440 \mathrm{~km}$ is two times the North-South extent of approximately $220 \mathrm{~km}$. Thus, the natural boundaries of the Niger Delta are expressly defined as noted earlier. By these definitions/boundaries, the states covered by the actual geographical Niger Delta are: Delta, Bayelsa and Rivers. According to Tamuno (2008), the current political definition of the Niger Delta to include Edo,Ondo, Akwa Ibom, Cross River, Abia and Imo States is a wrong political innovation aimed at causing confusion in the southern part of the country and perhaps to mislead the international community. It is a wrong notion to include all oil producing states in the South to be part of the Niger Delta not minding the fact that these sister states share certain environmental problems in common with the people of the geographical Niger Delta Region. Therefore, Tamuno (2008) asserted that it is necessary to reiterate the fact that the size of the geographical Niger Delta is just about $25,640 \mathrm{~km}^{2}$ and not the acclaimed extended $70,000 \mathrm{~km}^{2}$ as put forward by NDDC (2003).

To further authenticate the size of the Niger Delta to be $25,640 \mathrm{~km}^{2}$, Ashton-Jones (1998) classified the ecological zones of the Niger Delta into four and added them up to get the total size shown below:
Ecological zone
i. Low land Area
Approximated Area
ii. Fresh Water Swamp
$7,400 \mathrm{~km}^{2}$
iii. Salt Water Swamp
iv. Sand Barrier Islands
Total
$11,700 \mathrm{~km}^{2}$
$5,140 \mathrm{~km}^{2}$
$1,140 \mathrm{~km}^{2}$
$25,640 \mathbf{k m}^{2}$

The Niger Delta region has often experienced one period of boom after another in alternation between several natural resources. As Olatubosun (1975) observed, there was the boom era associated with exploitation of agricultural cash crops such as palm oil, timber, rubber, etc. However, the discovery of petroleum oil in Oloibiri in the region in 1958 marked a watershed in general exploitation and mining operations in the area. 
Following the oil boom in the 1970s, the Nigerian government shifted emphasis from the farmlands to the oil fields with excessive exploration and exploitation of the Niger Delta environment. The implications Dokpesi et al (2004) noted, were that apart from the fact that it altered the nature of the Nigerian economy from multi-product to mono-product; it created excessive wealth for the national economy while the oil producing communities were left with socio-economic and ecological crisis. For once, according to Jike (2004), Nigeria embarked on a novel exploration of a natural resource that had ample ramifications for the collective upliftment of the citizenry and in the euphoria that greeted the discovery of oil, many even began to coin utopian labels such as "black gold" and so on. Sadly, time has proven many wrong. The anxiety and expectations surrounding the discovery of oil have waned because the general livelihood of the people has not been positively affected by the oil discovery.

The Niger Delta region according to Omene (2001) generates $90 \%$ of the nation's export earnings and about $70 \%$ of revenue accruing to the federation account yet it is the most neglected, repressed, ecologically devastated and underdeveloped region in Nigeria. World Bank (1995) report observed that cases of water borne diseases and poor transportation in the Niger Delta are the worst in the country. Water transportation which is the main means of travel, is so costly that many cannot afford to use it, even when there is emergency. For the better part of the year, floods compel schools to close down.

The most pervasive and predominant cause of environmental degradation in the Niger Delta is oil spillage and gas flaring arising from oil exploration and exploitation. This concern, however does not reduce the importance of other environmental issues such as bush burning, erosion of various configuration, indiscriminate waste disposal etc. The problems of development in the Niger Delta region are numerous and complex. The solutions to these varied problems may well lie in the thorough understanding of the dynamics of oil spillage, gas flaring and the effects of poverty on the people.

\section{Oil Spillage and Gas Flaring in the Niger Delta: An Analysis}

All over the world, environmental pollution is an issue of great concern because of what the environment is to the human survival and indeed, the survival of the earth itself.

The most pronounced or visible devastation of the fragile Delta ecosystem occurs in the process of transportation of crude oil. According to Ifeadi et al (1985), Nigeria is considered to be among the worst oil spill and by extension, oil polluted nations of the world. Between 1970 and 1982, a total of 1,581 spillages were reported in Nigeria with a total loss of $1.67 \mathrm{~m}$ barrels of oil. Between 1982 and 1992, of the total oil spillages recorded by the Shell Petroleum all over the world, $40 \%$ came from Nigeria despite the fact that Shell's oil output in Nigeria was put at only about $14 \%$ of the worldwide product output (Gilbert, 1999). Between 1976 and 1996, a total of 4,835 spillages were recorded in Nigeria with an average of 440 per annum.

The issue of oil spillages is a common phenomenon in the Niger Delta region more than any other part of Nigeria. According to Ikporukpo, (2000) $98 \%$ of the transportation of crude oil in Nigeria, take place within the Niger Delta, because of the numerous oil fields, flow stations and terminals through which crude oil flows. About $25 \%$ of the total oil spilled in the Niger Delta between 1976 and 1990, was in the swamps; 69\% offshore while 6\% was recorded on relatively dry land (NDES, 1997). Similarly, Ikporukpo (2000) observed that the three largest spills in Nigeria have been: the Forcados terminal incidence of 1979 in which about 570,000 barrels were spilled; the Apoi North, 20 spill of 1980 in which 280,000 barrels were spilled; and the Idoho spill of 1998 in which about 40,000 barrels were spilled.

The Ministry of Petroleum Resources in Nigeria revealed that between 1976 and 1990, there were 2,676 recorded spills. It attributed 3.8percent of the spill to equipment malfunction, 21 percent to corrosion of equipment and 18 percent to sabotage. Okoye (1996) however stressed that sabotage of oil installations, which accounts for a significant number of spill incidence in the Niger Delta, are informed by protests, which is an expression of conflict between the host communities and the oil companies. Furthermore, one of the greatest sources of environmental degradation common with the oil and gas industry in Nigeria is "gas flaring". Studies according to Dokpesi et al (2004) have shown that Nigeria flares more gas than any other petroleum producing country. The World Bank (1995) observed that in 1991 whereas less than 5\% of the world's product was flared, that for Nigeria was $76 \%$. Nigeria's percentage was more than 15 times the world's and more than 4times the OPEC average.

According to Nwafor (2006), the sources of oil spillage and gas flaring in the area, comprise:

Spills, discharges and explosions both accidental and operational as well as sabotage -inspired by disgruntled and unhappy rural host communities along the dense network of oil and gas pipe-lines which crisscross the Niger Delta and the nation-wide links to inland refined petroleum depots (Ezeanozie,1991);

Pollution from oil tanker traffic and ballast discharge due to oil tanker transport and operations which generate accidental spills and ship-based wastes, inadequate port facilities at the nation's four tanker ports and the major shipping harbour at Port-Harcourt, all within the Niger Delta;

Lack of preparedness for oil spill contingencies despite the risk of major tanker accidents and operational spills offshore; 
Persistent damage in areas exposed to large and repeated spills like the already industrialized areas surrounding the oil terminals, refineries and gas glaring point;

Accidental spills of refined petroleum products including lubricating oil in the course of transportation, storage, marketing and utilization of petroleum products (Nwankwo and Ikechukwu, 1981; Nwankwo and Ifeadi, 1988);

Chronic operational and accidental oil spills and leaks from oil and gas operations in the face of the poor state or lack of preparedness in prevention and damage control when accidents such as fire outbreaks and spillages occur; Cutting of seismic lines and accompanying detonation of explosives at the exploration stage and waste from drill cuttings and drill mud at the drilling stage.

\section{Socio-Economic Consequences of Oil Spillage and Gas Flaring in the Niger Delta}

Although the first exploration well in Nigeria was drilled at Ihuo in Owerri in 1951, the first successful well was drilled at Oloibiri in the present day Bayelsa State, in 1956. However Oil and Gas News (1965) observed that its actual search started in 1937, abandoned during the Second World War and later resumed in 1946. Fagade (1990) noted that between 1956 and 1958 more oil wells were discovered at Afam, Bomu and Ebubu and later in Ughelli and Kokori. By the end of 1959, the production of oil was put at 12,000 barrels per day (bpd) and later 900,000 bpd in 1970. Van Heeswijk (1970) similarly noted that by this period, oil had become such a "black gold" that of the total surface area of Nigeria, put at 375,000 square miles, some 49,000 square miles of it had been allocated to oil exploration and production in the form of 20,500 square miles of oil mining leases.

Ifeadi et al (1987) contended that the steady increase in the number of oil wells discovered was phenomenal such that between 1960 and 1985, a total of 3,525 oil wells were dug in various ecological zones of the Niger Delta. However oil production in this region is currently put at approximately 2 billion bpd (Anya, 2000).

Sadly, the Niger Delta which has been variously described as the heart-beat of the nation's economy has known little peace as the area has remained conflict prone with vociferous agitation against the federal government for the control of its abundant resources. As Ukoha (2003) observed, the relatively backward communities that fall within the informal administrative zones of the south-west, south-south and south-east of Nigeria have complained excessively about the pains of exploitation and neglect in their long struggle with glaring and hazardous ecological problems. These problems Ukoha(2003) stressed, have arisen out of the intensive oil prospecting activities of various multi-national companies.

By far the most significant problem in Nigeria in the $21^{\text {st }}$ century measured by its human, socio-economic, ecological and physical impacts, is that of concentrated oil and gas pollution in the highly sensitive ecological and aquatic environment of the Niger Delta and other parts of the coastal zone and offshore. According to Nwafor (2006) locally, oil and gas activities have been associated with environmental impacts which are visible, intense and cumulative. He contended that the magnitude of the adverse social and environmental impacts is closely related to the nature of oil and gas prospecting and exploitation, with its massive need for land disturbance, removal of vegetation and environmental degradation on a scale frequently beyond the imagination of those in the affected communities. Often adverse physical impacts such as river siltation and water contamination are compounded by the influx of large number of outsiders into the oil cities such as Warri and Port Harcourt as well as in remote settlements and communities. Other impacts arise from possible resettlement of parts of the community and excessive pressure on every type of natural resource.

Akpofure et al (2000) noted that when there is an oil spill on water, spreading takes place immediately. The gaseous and liquid components evaporate while some get dissolved in water and even oxidize and some undergo bacterial changes and eventually sink to the bottom by gravitational action. The soil is then contaminated with gross effect upon the terrestrial life. As the evaporation of the volatile lower molecular weight components affect aerial life, so the dissolution of the less volatile components, with the resulting emulsified water affects aquatic life.

Similarly, a preliminary survey by Akoroda (2000), showed that an emergent trend of carcinogenic diseases in the Niger Delta is traceable to the exposure of these people to the radioactive elements of gas flaring. The people of the area Akoroda observed are beginning to develop symptoms of bronchial and respiratory diseases which are effects of long exposure to gas flaring.

Fagade (1990) argued that the various spillages no matter how minor, create undesirable change in the physical, chemical and biological characteristics of the air, water and land. Spilled oil for him has degradative impacts on flora and fauna of the ecosystem. The economic life of the people in each of the affected areas such as farmlands, navigational activities and fishing are disrupted.

The Environment Rights Action (ERA) also confirmed that the chemical components of flared gas comprise degradative elements such as hydrocarbons, sulphur oxides, nitrogen oxides, carbon oxides, ozone, particulate, photochemical ash and hydrogen sulphicide. These chemicals, according to Civil Liberties Organization (1999) threaten the survival of both human and wild life. Besides these devastating effects is the attribution of acid rain to gas flaring (NDES, 1997) as well as the emission of about $30 \%$ of the flared gas as methane, with a global warming potential of 64 times more than carbon dioxide. 
Apart from the loss of land, there are also more fundamental environmental problems of permanent damage to flora and fauna. Excessive exploration and seismic activities have negative consequences for soil toxicity and the quality of crops. There is a general concern by environmentalists that the quality of crops in the Niger Delta is rapidly deteriorating. The quality, size and shape of traditional staples such as cassava, yam, plantain etc, are adversely affected by the continuing forage for oil without the requisite Environmental Impact Assessment (EIA) (Akoroda, 2000).

Rural - Urban migration is another evil effect of oil exploration in this neglected region, which is largely rural. Having been displaced from their farms and unable to meet their obligations, some of these rural dwellers, especially the younger ones, are tempted to take their destinies in their own hands by resorting to crime or migrate in search of greener pastures far way in the urban centers (Mabogunje, 1968).

\section{Power Structure, Social Attitudes and Values: Perceived Injustice of Rule by Might and Exploitation}

The Niger Delta has been described as a pathetic paradox; so rich and yet so poor; so endowed and yet so mismanaged; so much potentials and yet so prodigal. How this burgled democracy has managed to hang together is a subject of study. How a system managed by a self-seeking few and their collaborators as personal fiefdoms, where the rich get richer and richer than the state itself and which squeezes life out of citizens and opponents alike, survival is indeed a marvel. The region is a predatory contraption in which power is based not on the usually recognized broad public support but on force or coercion (military or locally sourced mercenary) and the impact of a narrow kleptocratic self-seeking elite and in which state power faces few constraints. The elite maintain the exploitation of public and private resources for the gain of themselves through institutionalized practices by which oil revenues and crude oil are controlled and stolen to grease the functioning of an intensive machinery of rent seeking and political patronage (Nna and Nyenke, 2004: 119).

As an elaboration, we are saying that in case of conflict within societies over surplus sharing, the parties involved are usually motivated to take the issue to the final court of appeal of force or coercion, as it is in the region, so long as there is likelihood of benefiting by so doing (Lenski 1973:259). But it has been demonstrated that force is not the most effective instrument for retaining and exploiting positions of power and deriving maximum benefits therein, even though it is indispensable for achieving power. This is because rule of might (which is based on force or coercion) is inefficient, unstable and costly, as much of its benefits are eroded by the cost of coercion and its concomitant denial of legitimacy.

According to Lenski (1973:255):

The use of force alone is but temporary. It may subdue for a moment; but it does not remove the necessity of subduing again; and a nation is not governed, which is perpetually to be conquered.

Lenski (1973) argued that for optimum operation, there must be a shift from the rule of might (based on force and coercion) to the rule of right, based on institutionalized justice and moral order freely accepted by the majority as their own.

In addition to being a paradox, the Niger Delta is also becoming a norm less society: a society in a state of anomie. The seeming paradox is how a situation of utter formlessness can foster substantive development that will provide the greatest good for the greatest number. The reality in the region, approximates, more or less, Durkheim's conceptualization of anomie, a state of absolute lack of control and deregulation such that the collective no longer control peoples desires and passions.

While trying to paraphrase Emile Durkheim's postulations, Turner and Beeghley (1981:343) have succinctly indicated that "for Durkheim, this dilemma was expressed in terms of maintaining individual's commitment to a consensus of values and beliefs while at the same time allowing them to pursue their specialized interest." At this stage in Durkheim's thinking, anomie represented insufficient normative regulation of individual activities with the result that they do not feel attached to the collectivity. In a nutshell, therefore, according to Turner and Beeghley (1981:343):

Anomie is inevitable when the transformation of societies from a mechanical to organize basis of social solidarity is rapid and causes the generalization or enfeeblement of values.

The trust of this section is that prevailing values and the interoperation of development have been mediated by extraneous factors such as ethnicity, corruption and other primordial considerations that have little bearing on development per se. Development has, therefore, come to mean different things to individuals in the Niger Delta, depending on their ethnic self-identity, class privileges, status position and primordial orientation.

In the Niger Delta region, this great deposit of oil and gas has become a mixed blessing for the people. According to Akpomuvie (2008), they are denied the benefits of this wealth and exposed to devastating environmental pollution and degradation. Oil spillages have become recurrent and routine in the region. Furthermore, the people of the region are impoverished and marginalized due to the inequitable and defective federal system of government practiced by the Nigerian state.

Although oil has been used with some measure of success to hold together, a fragile political coalition of diverse ethnic and religious interests, economic infrastructures have remained underdeveloped and the broad provision of 
public goods is scarce. This development has created social tension, particularly in the oil-producing communities, which being relatively politically powerless, have had little or no benefits from oil exploration or production activities. In this regard, there is a group sense of deprivation and marginalization, which has pitched the people against the oil companies and by extension, the state. As Nna (1999) has observed, it is this feeling of deprivation and marginalization, which underscores most of the conflicts in the Niger Delta including of course, the whole question of sabotage, induced spillages and hostage taking of particularly expatriates and recently Nigerians.

It is in a bid to overcome the problem of disempowerment resulting from marginalization and the destruction of local economies, that individuals take to sabotage of oil installations. Okoko and Nna (1998) have observed that there exist, mobile sabotage squads in the oil-producing communities. They are professionals who move from one community to the other, with hack saws, loosening oil pipeline manifolds to release crude into farmlands, stream swamps and fishing grounds and to demand for payment of compensation. An important aspect of the revelation is the connection between the mobile sabotage squads, spill cleaning contractors, officials of oil companies and officials of the Ministry of Petroleum Resources.

At the core of the problem is an enactment called revenue allocation formula. In the years immediately following independence when Nigeria relied mainly on cash crops such as groundnuts and cotton (for the North) cocoa (for the West) and palm oil (for the East), the allocation was one hundred percent to the generating region. But as earnings of massive petroleum - dollar eclipsed earnings from agriculture; the ruling elite from the three dominant groups (Hausa-Fulani, Yoruba and Ibo) connived, using the levers of the federal political power to alter the formula to favour them and deny the indigenes of the Niger-Delta oil bearing communities. Prof. Aboyade started the dance of deception by his deliberately contrived revenue sharing formula which drastically reduced the weight attached to derivation and placed the weight on landmass, population, etc.

The height of this dance of deceit was President Ibrahim Babangida's total abolition of derivation from the formula (Jike, 2002:13). Babangida then resorted to dolling out financial tokens to the oil bearing states while the federal government; himself, his cronies and agents, exploited and stole the oil revenues and crude oil which they sold on the spot market. Today, former Nigerian military President Babangida and his cronies and agents are still rolling in looted petroleum -dollars with which they are now attempting to buy themselves back to power as civilian leaders.

Everywhere the peoples of the oil bearing states looked they perceived evidence of rule by might; exploitation and neglect. As far back as before the Nigerian civil war, Adaka Boro gave a hint of what is to come as a now full-blown Niger-Delta crisis, when he declared the short lived Republic of Yenogoa as a break-away republic from Nigeria. This same perception produced Ken Saro-Wiwa and the Movement for the Survival of the Ogoni People. This perception also produced the Kiama Declaration and the various social political movements that produced it. The most recent expressions of this perception are the various militia groups and their leaders, such as Asari Dokubo. The National Conference organized by the Obasanjo Administration in 2004, was an attempt to give opportunity to the representatives of the Niger-Delta to let off steam and thereafter allow the exploitation of the internal colonizers to continue. It was therefore no surprise that the modest demand for a review upward of the derivation percentage going to the oil bearing states, was shot down with derision by the representatives of the internal colonizers at the conference.

\section{Multinational Oil Companies and the Development Crisis in the Niger Delta}

Perhaps, Nigeria would have remained a major agricultural country if petroleum oil was not discovered in Oloibiri in 1958. A rash of multi-national companies got into the fray of prospecting for oil. The companies which eventually obtained Oil Prospecting Licences (OLP $\backslash \mathrm{s}$ ) include: Mobil Oil Company (Nigeria) Limited, Pan Ocean (Nigeria) Limited, Niger Oil Resources Limited, Japan Petroleum Company (Nigeria) Limited, Tenneco Oil Company (Nigeria) Limited, Safrap Oil Company (Nigeria) Limited, Elf (Nigeria) Limited, Agip Oil Company (Nigeria) Limited, Phillips Oil Company (Nigeria) Limited, Texaco Oversea Petroleum Company, Ashland Oil Company (Nigeria) Limited and the Nigerian National Petroleum Company which is wholly owned by the Federal Government of Nigeria (Jike, 2004).

As Egborge (2000;96) observed, it is a well known existential truism that a good parasite does not kill its host. Contrary to this truism, the oil companies operating in the Niger Delta have been very bad parasites on the host communities.

They have operated at below internationally allowed environmentally friendly standards. Oil exploration in the region is being carried out without regard to international health and safety standards or observed minimum levels of protection of the environment from chemical pollution, in the air, land, rivers and water table. Gas flaring has continued unabated because it is cheaper to produce oil in Nigeria with gas flaring because the federal government and the oil companies are not yet ready to invest the necessary capital on the technology for the collection, processing and exportation of gas which would add tremendously to Nigeria's wealth.

They have continuously employed expatriates and "local foreigners" rake away petroleum and gas dollars from the backyard and waterfronts of the "aborigines of the Niger Delta" who sit idle with their eyes open (Egborge, 2000:96). 
When the people out of frustration and justifiable anger protest, they are mowed down as in Odi in Bayelsa State. The oil companies employ the divide and rule tactics on the host communities by turning the youths against the elders and their traditional rulers.

They have corrupted the Environmental Impact Assessment (EIA) system by often giving EIA studies to incompetent but well connected consultants, who turn in useless reports to fulfill FEPA requirements.

The oil companies and their staff, live and operate from enclaves of civilization, opulence and luxury in the squalor that is experienced by the communities around them.

It is a well known open secret ,that no one knows how much crude oil, that is actually produced and sold in Nigeria daily. The federal government, the NNPC and the oil companies are well aware of this fact. There is in fact a big gap between the officially announced production figures and actual production. This gap which likely runs into millions of barrels is made up of crude stolen by the oil companies; foreign nationals; government officials and other local plunderers.

\section{Environmental Impact Assessment (EIA) and Sustainable Development In Contemporary Development} Agenda.

The last two decades of the $20^{\text {th }}$ century has witnessed the emergence and steady ascendancy of sustainability as a new development paradigm. This new trend resulted in recasting environmental issues in the context of sustainable development. (Munasinghe, 1999). The driving forces have been the shift in paradigm from growth to sustainability and the attendant steady increase in understanding, acceptance, adjustment and implementation of the concept of sustainable development. Consequently, since the 1990s, the concept and its practical implementation have been increasingly considered by policy makers to be one of the most critical tools of achieving a balance between economic, social and environmental objectives. According to (Angelson, Odd-Helge and Sunlaila, 1994; Carew-Reid et al, 1994; Munasinghe, 1993 and 1999) this has been the case in developed countries and most developing countries.

There are many definitions of sustainable development. However, many contemporary definitions focus on the holistic approach to planned change which takes into account, the consequences for future generations. Bruntland (1987) see sustainable development, as paths to human progress that meet the needs and aspirations of the present generation without compromising the ability of future generations to meet their needs. It also requires political reforms and more just and equitable distribution with and among nations. As rightly pointed out by Pearce and Warford (1980), sustainable development is a process in which natural resource base is not allowed to deteriorate. They emphasized the hitherto unappreciated role of environmental quality and environmental inputs in the process of raising real income and the quality of life.

Environmental Impact Assessment according to Eugine (2005), is a technique for ensuring that the likely significant effects of new development on the environment are fully understood and taken into account before it is allowed to go ahead. It also describes the whole process by which information about the environmental effects of an industrial project is collected, assessed and taken into account by public authorities in reaching a decision on whether the proposed development should go ahead or not

Environmental management professionals and exports in developing countries have an interest in getting to grips with a clear appreciation of the importance, significance, implication and benefits of promoting sustainable development through EIA (Nwafor, 2006). This is because EIA has become an avenue whereby the principles of sustainability can be integrated into the country's development activities. One environmental expert, who has explored wide-ranging aspects of impact assessment and sustainable resource use, is (Smith 1997, 1989, 1990, 1993). Based on his experiences, he made a strong case for a redefinition of the role of environmental impact assessment in order to enhance its capability as an instrument for achieving the goals of sustainable development (Smith, 1993).

In Nigeria, the Environmental Impact Assessment Decree was established in 1992. The Decree requires the government, its agencies and private enterprises, to take significant steps before engaging in projects that may have environmental repercussions, from initial planning to implementation and afterwards. One of such steps is to compulsorily put in place, in projects which may significantly affect the quality of the environment, a detailed assessment concerning the environmental impact of the project. This assessment should include: adverse impacts that cannot be avoided, alternatives to the proposed action, cumulative, long and short term effects, identification of measures available to mitigate adverse effects and an indication of cross-border effects. The law requires the publication of such assessment to enable interested parties, to examine the environmental propriety and, if need be, object to the purposed project or activity before its commencement. It also stipulates various penalties for non-compliance and incorporates in its schedule, a list of activities or projects for which environmental impact assessment is mandatory. Despite the provision, the government does not seem to have made any positive impression on the people of the Niger Delta.

\section{Legal Regulations in the Nigerian Oil and Gas Industry}

Several laws regulate the activities of the oil industry vis-à-vis, the environment. These include:

The Petroleum Act, Cap 350, LFN 1990 and its attendant regulations. 
The Oil in Navigable Waters Act Cap 331, LFN 1990 and its attendant regulations.

The Oil Terminal Dues Act Cap 339, LFN 1990.

The Associated Gas Re-Injection Act Cap 26 LFN 1990 and its attendant regulations

The Federal Environment Protection Agency Act Cap. 131 LFN 1990.

The Petroleum Act generally empowers the Minister in Section a - (1) (b) (iii) to make regulations for the prevention of pollution of water courses and the atmosphere. Accordingly the Petroleum Regulations 1969 contain provisions on environmental pollution. There is an omnibus provision on pollution in Regulation 25, which provides that:

The licensee or lessee shall adopt all practicable precautions including the provision of up-to-date equipment approved by the Director of Petroleum Resources to prevent pollution of inland waters, rivers, water courses, the territorial waters of Nigeria or the high seas by oil, mud or other fluid or substances which might contaminate the water, bank shore line which might cause harm or destruction to fresh water or marine life and where any such pollution occurs or has occurred, shall take prompt steps to control and if possible, end it.

The Federal Environmental Protection Agency Act was enacted in 1988, after a long gestation period of 12 years. It is the first Nigerian Statue to deal exclusively with the environment. The Act establishes the Federal Environmental Protection Agency, which is to be responsible for the protection of the Nigerian environment. Among others, the Act prohibits the discharge of hazardous substances (including crude oil) into the air or upon the land and the waters of Nigeria. Unlike the other legislation (which provide for only criminal sanction for its breach or the payment of compensation for damage consequent there to, as the case may be), this law provides for both criminal sanction and civil liability for its breach and consequent damage. Regarding civil liability, section 21 therefore categorically states that any person (particularly an oil company) who contravenes the prohibition of section 20 shall, in addition to the penalty specified in the section, be liable for: (a) the cost of removal thereofincluding any costs which may be incurred by any Government body or agency in the restoration or replacement of actual resources damaged or destroyed as a result of the discharge and (b) costs of third parties in the form of reparation restoration, restitution or compensation as may be determined by the Agency from time to time. However, such a person shall not be liable if he proves that the discharge was caused solely by a natural disaster or an act of war or by sabotage.

Furthermore, section 36 of the Act, specifically provides that where any corporate body (for example, an oil company) contravenes any provisions of the Act or any Regulations made there under, every director or officer of that body shall be directed to "pay compensation" and to "restore the polluted environmental area to an acceptable level as approved by the Agency" unless he proves to the satisfaction of the court that (a) he used due diligence to secure compliance with the Act: and (b) such contravention was committed without his knowledge, consent or connivance. To be sure, it seems the idea behind this, is to make oil company managers, personally accountable for environmental degradation and thereby encourage them to ensure compliance with relevant environment protection statues.

The Oil in Navigable Waters Act, 1968 (and the Regulations made there under) is an elaborate anti-pollution (specifically, water pollution control) law. According to its preamble, it is an Act to implement the terms of the International Convention for the prevention of pollution of the sea by oil 1954 to 1962 and to make provisions for such prevention in the navigable waters of Nigeria. Etikerentse (1985: 64) surmised that 'the primary aim of this legislation, is to reduce the incidence of pollution of the World's High Seas generally and of Nigerian waters in particular. Five pollution-related offences are created by the Act under sections 1, 3, 5, 7 and 10 respectively. Essentially, they relate to the prevention of pollution of water by sea going vessels (ships) both Nigerian and foreign vessels. Under section 6 of the Act, any person who violates the provision of this section, shall on conviction by a High Court or a superior court or on summary conviction by any court of inferior jurisdiction, be liable to an unspecified fine.

Oil Pipelines Act is another important law in the field of environmental claims, particularly in cases of oil - related environmental damage. According to its preamble, it is an Act to make provision for licenses to be granted for the establishment and maintenance of pipelines incidental and supplementary to oil fields and oil mining and for purposes ancillary to such pipelines. Under section II (2) thereof, 'oil pipeline' is defined as 'a pipeline for the conveyance of mineral oils, natural gas and any of their derivatives or components and also any substance (including steam and water) used or intended to be used in the production or refining or conveying of mineral oils, natural gas, and any of their derivatives or components. Essentially the Oil Pipelines Act, is particularly concerned with the laying (establishment) of pipelines- the Act provides for the issuance of permits to survey and oil pipeline licenses, authorize the holder of a permit, to enter the land specified in the permit or any adjoining land thereto. Even so, there are important environment protection-related provisions therein.

The Harmful Wastes (Special Criminal Provisions) Degree of 1988 is yet another vital law in the oil and gas industry in Nigeria. This was enacted in the wake of an incident when some Italian companies, with the collaboration of some local officials and citizens, imported and deposited some highly toxic and radio-active waste materials on a farmland, near the port at Koko town in Delta State. The Decree creates criminal offences in respect 
of movement, handling and disposal of toxic and generally harmful substances on any land or territorial waters or contiguous zone, or Exclusive Economic Zone of Nigeria. It stipulates very stiff penalties.

\section{Sustainable Development of the Niger Delta Region}

Addressing the Niger Delta region's many development challenges begins with using its vast oil wealth to create an environment in which the people can flourish. People of the area should be able to live valued and dignified lives, overcome poverty, enjoy a peaceful atmosphere and expect a sustainable environment. For development to be meaningful, people-centered and sustainable in the region, this paper proposes a six point human development agenda: promotion of peace as the foundation for development, make local governance effective and responsive to the needs of the people, promote social inclusion, access to social services, environmental sustainability to preserve the means of the people's sustainable livelihoods and build sustainable partnerships for the advancement of human development in the region.

Diversification of the economy of the region from oil to the development of renewable resources especially agriculture, is vital for the transformation of the area. Fishing and agriculture are the major traditional occupations of the Niger Delta peoples. During the colonial era, forestry was introduced as the third major economic activity in the region. Today, agriculture, fishing and forestry still account for about 44 percent of employment. All the three economic activities have declined since the ascendancy of the oil industry. Rubber plantations that once covered thousands of hectares of land in Edo and Delta States were cleared as the oil boom took hold while many palm oil and cocoa plantations were abandoned and allowed to revert to bush. One major contemporary challenge facing the region's economy may be how to revamp the rural economy by optimizing and modernizing agriculture as well as fishing. Oil wealth can be put to good use in this regard as the people of the region, would feel they have gained something substantial to make up for all the miseries associated with past neglect.

Individuals and communities in the Niger Delta Region that had suffered environmental damage from oil industry activities have the right to compensation. An injunction restraining the activities of an oil company is unlikely to be granted by any court because of the strategic importance of the oil industry. In this regard, the main law appears to be Section 36 of schedule I of the Petroleum Act, 1969. This provision provides for the payment of "fair" and "adequate" compensation. Other provisions are Regulations 21 and 23 of the Petroleum Regulations, 1969 which speaks of "fair" and "adequate" compensation respectively. These terms are highly subjective and are not defined within any enactment. Section 36 schedule I of the Act and Regulation 21 refer to unmentioned surface rights and to specified plants. However, so many rights and interests may be affected, such as those pertaining to fish pounds, fish farms, water ways, canals, wild life sanctuaries and so on. In some states, there are edicts dealing with the procedure and quantum of compensation. An example is the Rivers State Minimum Crop Compensation Rates Edict 1973. The process of arriving at compensation figures is predicated on negotiations by the parties affected.

Ways of controlling environmental hazards have been clearly stated in the various laws and decrees of 1967, 1969 and 1969. Efforts should be focused on implementing these laws and decrees as a means of achieving development for the region. Regulation for Environmental Impact Assessment (EIA) Decree No. 86 of 1992, which makes it mandatory for development projects to put in place appropriate mitigative measures, to address identified significant environmental problems, should be monitored by the government and ensure strict compliance. In compliance, the oil prospecting companies should consult with affected communities, to conduct environmental impact assessment to identify significant impacts of its intended operation projects in the area. The idea is to provide mitigating remedial assistance to correct identifiable negative impact.

The politics and dynamics of revenue allocation have also manifested in attempts to address the peculiar development challenges of the Niger Delta as an oil producing region. The idea was that revenue should be shared, in proportion to the contribution that each region made to the common purse or central government. Derivation became the only criterion used to allocate revenues among the regions in the 1948-1949 and 1951-1952 fiscal years. In the period shortly before independence in 1960, the disparity in allocation largely reflected the degrees of enterprises and levels of production in the regions. This meant that by merely looking at the levels of allocations, one could easily discern the regions with high levels of economic activities in areas such as cash crops production (e.g., Cocoa, rubber, palm oil, cotton, hides and skins, groundnuts, etc), earnings from export and excise duties and so on. Between 1946 and 1960, the derivation principle was maintained at 50 per cent till 1967, when the Nigerian civil war started. The 1960 and 1963 constitutions affirmed the 50 percent rate as reflected in Section 140 of both documents. The 50 percent derivation formula changed in varying ways during the military and civilian administration eras to mere 3 per cent and recently to 13 per cent now that oil is the mainstay of the Nigerian economy.

Many citizens of the Niger Delta may be forgiven for believing that, if the mineral oil was found in the areas of the major ethnic groups, who incidentally have been ruling Nigeria since independence rather than in the minority areas, the derivation story may have been different. The pros and cons of this argument notwithstanding, the bottom line, is that a credible and equitable revenue allocation formula, represents a viable way of lessening the tension, agitations and perceptions of unfairness, if not total disillusionment in the Niger Delta. Correspondingly, 
the implementation of a viable programme for rapid human development would be a lot easier to achieve with a revenue allocation formula that the peoples of the delta could consider equitable and acceptable.

In addition to the payment of equitable derivation fund to the oil and gas producing states, the federal government should also abolish effectively and totally, the dichotomy between the onshore and offshore formula that is currently applied in the payment of funds, since such dichotomy is not stipulated in the 1999 constitution. Apart from reviewing all oil exploratory laws in the country, the Federal Government should promulgate laws compelling oil and gas exploration companies, to pay 10 percent of their annual profit to the Central Bank account of the Niger Delta Development Fund. Again, penalty fees should be paid into the aforementioned account for environmental degradation. Two percent levy should be imposed on each barrel of crude oil extracted at the local rate per barrel of crude oil. This should be paid into the Development Fund to be managed by experts drawn from within and outside the delta.

Other measures should also be looked into for the sustainable development of the area. Among others, every state in the Federal Republic of Nigeria should be permitted by law to control its resources, the abrogation and repeal of all laws that expropriate the rights of the people to control their resources such as: Territorial Waters Act Cap. T4Laws of the Federation of Nigeria 2004, Exclusive Economic Zone Act, Cap. E17-Laws of the Federation of Nigeria, 2004, Land Use Act, Cap L5- Laws of the Federation of Nigeria, 2004, Interpretation Act Cap. P10- Laws of the Federation of Nigeria, 2004, Oil Pipelines Act Cap.07- laws of the Federation of Nigeria, 2004, Minerals and Mining Act,Cap.M12- Laws of the Federation of Nigeria, 2004, National Inland Water ways Authority Act Cap. N47- Laws of the Federation of Nigeria, 2004, Section 44 (3) of the 1999 Constitution and item 39 on the Exclusive Legislative List of the 1999 constitution, banning of gas flaring in the Niger Delta, Oil Companies should relocate their headquarters to their areas of operations in the South-South, preferably in the creeks where they have their flow stations, Niger Delta Development Commission(NDDC) should be compelled as a priority, to provide all reverine oil-bearing communities in the South-South with light, portable water, good roads and hospitals and the multinational Oil Companies should be compelled by law to employ the youths in the South-South in both skilled and unskilled labour, especially those operating in the riverine oil communities.

The development of the Niger Delta region cannot be the responsibility of any one level of government alone. While the Federal Government can take the lead on overarching issues influencing development in the region, it has to work with other stakeholders and partners if development in the region, is to be sustainable and meaningful.

\section{Conclusion}

In the light of the above discussions, it is obvious that this great deposit of oil and gas has become a mixed blessing for the people of the Niger Delta. They are denied the benefit of this wealth and exposed to devastating environmental pollution and degradation. For example, as at 2002, about N450 million worth of associated gas was being wasted by flaring daily. The annual loss is valued at N164 billion. Oil spillages have become recurrent and routine in the area. It is now well known that these spillages in combination with other toxic wastes and effluents dumped into the waters and land at every stage of oil exploration and exploitation, have destroyed farmlands, economic crops, water including groundwater resources, biodiversity etc. Furthermore, the people of the region are impoverished and marginalized due to the inequitable and defective federal system of government practiced by the Nigerian state.

All these devastating environmental impacts of oil exploration, exploitation and transportation, coupled with the many years of neglect and defective intervention policies have generated criminal activities and a condition of underdevelopment in this region. What the state defines as criminal is not necessarily criminal in the people's interpretation. Vandalization of petroleum oil pipelines, abduction and kidnapping of expatriate personnel of multinational oil companies and the bunkering of crude oil in the creeks of the Niger Delta can be used to illustrate the prevailing obfuscation in the interpretive understanding of these crimes. Uprooted out of a once fertile farmstead, displaced by incessant oil spillages and desperate to survive against all odds, the Niger Delta youths begin to accentuate the scope of acceptable behavior into the realm of deviance and criminality. The youths see nothing wrong in militancy, vandalizing oil pipelines, kidnapping and abduction or bunkering for crude oil.

It is rather unfortunate that oil exploration in the Niger Delta is being carried out without regard to international health and safety standards or observed minimum levels of protection of the environment from chemical pollution in the air, land, rivers and water tables. Here lies the "tragedy of commons". This theory was put forth by Garrett Hardin (1968). It especially talked about the misuse of public property and its effects on the environment and humans as elaborated about the Niger Delta situation. Garratt explained this theory with the help of his famous shepherd's story. In it he stated that every shepherd is entitled to a pasture of land where he can allow his sheep to graze, but when he starts encroaching into another shepherds pasture, it has several effects. Firstly, the land, since it is over-grazed gets denuded and secondly, for want of food, the sheep begin to die.

The solution to the Niger Delta crisis requires both a long and short term perspective as highlighted earlier in this article. In the short run, there should be a Marshal Development Plan for the region. Massive funding must be put on job creation through industrialization, using the more effective strategy of public private partnership. Public funds must be employed with private funds but with the technical expertise and management as private profit 
oriented enterprises. As a context for this industrialization, the government needs to invest massively in the infrastructural development of the region, to open it up for industries and create the enabling environment for investments and production.

The ultimate long term solution is to take a total hard look at the Nigerian defective federation and restructure it to move away from the rule of might to the rule of right. This will require a national conference of the federating units to restructure and redefine the units and power relations. For example, it will require a hard look at the core issue of fiscal federalism and the revenue sharing formula. In this regard, the fight against corruption must not only continued but must be intensified and be sweeping instead of the present selective approach. Those who governed the oil bearing states must be held accountable to the people for the funds allocated for the actual development of the area during their office tenure.

\section{References}

Akpomudje, A. (2003). Environmental Claims Resulting from Oil Exploration and Exploitation in Nigeria. A paper presented at the Annual General Conference of the Nigerian Bar Association at Enugu, $27^{\text {th }}$ August.

Akpomuvie, O.B. (2008), Environmental Degradation, Poverty and the Problem of Sustainable Development in the Niger Delta. Nigerian Sociological Review, 3(1-2) pp 85 -92.

Amaechi, N. (2003). Environmental Claims: The Laws, Regulations and Practice. A paper presented at the Annual General Conference of the Nigerian Bar Association at Enugu, $24^{\text {th }}-30^{\text {th }}$ August.

Angelson, A, Odd-Helge, F and Sumaila, U.R. (1994). Project Appraisal and Sustainability in Less Developed Countries. Norway; Michelson Institute.

Ashton-Jone, N. (1998). The Human Ecosystems of the Niger Delta. Ibadan; Krat books, Ltd.

Carew - Reid, J. et. al. (1994). Strategies for National Sustainable Development. London; Earth Scan.

Dokpesi, A.O. et al. (2004). Environmental Degradation and the Prospects of Remediation in the Niger Delta. In Jike, V.T. (ed) Social problems: Theoretical Paradigms in Contemporary Sociology pp 88-106.

Egborge, A.B.M. (2000). Government, Oil Companies, the People and the Niger Delta Environment. Delta State University $4^{\text {th }}$ Convocation Lecture, April. Benin City; Ben Miller Books Nigeria Ltd.

Eugine, T. (2005). Environmental Economics. Delhi; Vrinda Publications (p) Ltd

Fagade. O.E. (1990). Bacteria Biodegradation of Crude Oil from the Niger Delta Region of Nigeria Unpublished PhD Thesis, University of Ibadan.

Ifeadi, N. Ekaluo, U and Orubuma. (1985). Treatment and Disposal of Drilling Muds and Cuttings in the Nigerian Petroleum Industry. Proc. International Seminar on the Petroleum Industry and Environment -NNPC, FMW\& H. Lagos.

Igun, U.A. (2008). Power, Distributive System and the Niger Delta Crisis. Nigeria Sociological Review, 3 (1and2)1-10.

Ikporukpo, B.C.O. (1988). Managing Oil Pollution in Nigeria. In Sada, P.O. and Odemerho, F.O. (eds), Environmental Issues and Management in Nigerian Development. Ibadan: Evans Brothers Ltd.

Ikporukpo, B.C.O. (2000). Petroleum, Fiscal Federalism and Environmental Justice in Nigeria. A paper presented at IFRA seminar series, university of Ibadan, September.

Jike, V.T. (2004). Environmental Degradation, Social Disequilibrium and the Dilemma of Sustainable Development in the Niger Delta of Nigeria. Journal of Black Studies, 34 (5)

Kilby, P. (1969). Industrialization in Our Open Economy. Nigeria 1945-1960. Cambridge: University Press.

Lenski, G. (1973). Power, Force and Morality in Chambliss, W.J. (ed) Sociological Readings in the Conflict Perspective. Addis on-Welsey Publishing Company, PP 254-269.

Mabogunje, A.L. (1968). Urbanization in Nigeria. London; University Press

Mudiaga-Odje, A. (2008). Niger Delta and the Politics of Oil. Warri; Jenique International Company Limited.

Munasinghe, M. (1999). Development, Equity and Sustainable Development in the Context of Climatic Change. Paper prepared for the IPCC Experts, meeting on Development, Equity and sustainability, Colombo, Sri Lanka, 27-29 April.

Niger Delta Environmental Survey (NDES). (1997). NDES Final Report. Vol. I. Lagos: ERML

Nna, W.K. and Eyenke, C. (2004). Oil Spillage, Sabotage and the Politics of Exclusion in the Niger Delta. in V.T. Jike (ed) Social Problems: Theoretical Paradigms in Contemporary Sociology. Lagos: NISS Publications, PP. 114-125.

Nwafor, J.C. (2006). Environmental Impact Assessment for Sustainable Development: The Nigerian Perspective. Enugu; El Demark Publishers.

Oil and Gas News. (1965). Oil Prospects in Nigeria. 11(4): 71 - 72. 
Okoko, K.A.B. (1996). Community Relations (SPDC).

Okoko, K.A.B. and Nna, N.J. (1997). Emerging Trends and Community Perception in the Nigerian Oil Industry. Nigeria Journal of Oil and Politics, 1(1).

Olatubosun, D. (1975). Nigeria Neglected Rural Majority. Ibadan; Oxford University Press.

Omene, G.E. (2001). Overview of NDDC Interim Action Plan, A Keynote address at the International Conference Workshop Organized by NDDC in Port Harcourt, 22 October.

Omorogbe, Y. (2001). Oil and Gas Law in Nigeria. Ibadan; Malt house Press Ltd.

Shell Petroleum Development Company. (1995). Nigeria Brief. The Environment. Lagos; SPDC.

Shell Petroleum Development Company. (1999a). Corporate Community Business Plan. Lagos: SPDC.

Smith, L.G. (1990). Canada's Changing Impact Assessment Provisions. EIA REVIEW, II(1): 5-9.

Smith, L.G. (1993). Impact Assessment and Sustainable Resource Management. U.K. Longman Scientific and Technical.

Turner, J.H. and Beeghley, L. (1981). The Emergence of Sociological Theory. Illinois: Irwin and Dorsey Press. UNDP. (2006). Human Development Report for the Niger Delta. Abuja; UNDP.

Van Dessel, J.P. (1995). The Environmental Situation in the Niger Delta of Nigeria. The Hague; Green peace. 